\title{
The Notion of Subhuman Identity in the WAR ON TERror
}

\author{
Jessica Singh, University of Victoria
}

\begin{abstract}
Foreign policies in the global political arena continue to demonstrate the consequential after-effects of the terrorist attacks in New York on September 11, 2001. Propagations of a "terrorist threat" are strategically used by Western political actors to achieve a multiplicity of ends. In some cases, these ends supersede accepted international precedents, both in the realms of international law and convention. In particular, United States President George W. Bush's War on Terror, and President Barak Obama's continuing drone operations in the Middle East exemplify instances of political transcendence. Through the strategic enactment of ambiguous laws and through intimate utilizations of notions of "state sovereignty" and "national self-defense," the American Government has gained unprecedented authority in the treatment of suspected terrorists. This article examines the legal, theoretical, and ethical elements of the War on Terror and the American drone operation in the Middle East to illustrate the exceptionalness of Al-Qaeda and Taliban combatants in American legal understanding.
\end{abstract}

Dwenty-first century Americans are living in an age of "Islamophobia," in which the enemy has been explicitly labelled. This phenomenon is not new; it has existed ever since Western colonialists first began their attempts to dominate the worlds of the "uncivilized." 'With regard to proto-colonialism for example, the Crusades represent one of Europe's first systematic attempts to

1 Hamid Dabashi, Brown Skin, White Masks, (New York: Pluto Press, 2011), 33. 


\section{The Notion of Subhuman Identity in the War on Terror}

annihilate Islam and to erase 'Eastern' identity from the world. Today, we see a similar phenomenon made manifest in the United States' strategies in the War on Terror, an ongoing international military campaign designed to eliminate enemy terrorist organizations The primary targets of this war, members of al Qaida and the Taliban, are depicted through the lens of an existential Western bigotry that has existed since antiquity. The notion of a divide between the Occident and the Orient is not one that has been generated from facts or reality, but rather from preconceived archetypes of the "Other." ${ }^{2}$ As Zachary Lockman suggests, the Westerner has historically considered the Oriental man an inherent "barbarian." ${ }^{3}$ Lockman illustrates various accounts of Western conquests that contend that the Oriental being's actions are sheer manifestations of his "barbaric" nature and that therefore, there exists an almost constant need for a superior interference. ${ }^{4}$ In this way, the perceived pitiful and inferior existence of the Oriental constitutes the noble and superior essence of the Westerner. Thus, in this preconceived Western notion, the Oriental being is a subhuman being. In this paper, I will use specific examples of American foreign policy and military strategy in the War on Terror to illustrate the American preconception of the subhumanness of al Qaida and Taliban militants.

As Hamid Dabashi provocatively argues, "brown has become the new black," and "Muslims are the new Jews." Since the events that have come to be termed "9/11," (the September 11, 2001 terrorist hijackings of four American passenger airliners that progressed into cataclysmic suicide attacks in New York City and Washington) al Qaida and Taliban combatants have been recognized by the American Government as the principal targets of its War on Terror. The criminal nature of the combatants' actions is often minimized, and the Government instead focuses on the supposed inhumanity of their conduct and what it implies about their essence as human beings. Through both policy and strategy, the American Governmenthas used the War on Terror to "dehistoricize" and transform the criminal

2 Zachary Lockman, Contending Visions of the Middle East: The History and Politics of Orientalism, $2^{\text {nd }}$ ed., (New York: Cambridge University Press, 2010), 13. 3 Lockman, Contending Visions, 10.

4 Ibid, 12-19.

5 Dabashi, Brown Skin, 6. 
events of 9/11 into events of inhumanity. ${ }^{6}$

Within the American System of Criminal Justice, there exists a stark disparity between the lawful treatment of al Qaida and Taliban combatants and that of citizen criminals. Although sentencing in the United States varies by state, life imprisonment and "humane" forms of capital punishment are the severest penalties available; the American Constitution's Eighth Amendment prohibits the Government from imposing "cruel and unusual punishment" upon criminals. ${ }^{7}$ By virtue of this constitutional clause, any act of torture is outlawed in the United States. However, since accused members of al Qaida and the Taliban are not U.S. citizens, they are excluded from the protections of the Eighth Amendment. For this reason, their right to ethical treatment as non-citizen criminals held in U.S. custody is an explicitly contentious issue.

Despite the U.S. Constitution's prohibition of the use of torture, retired Harvard Law professor Alan Dershowitz, has controversially argued for its legislation as a tool in the interrogations of suspected terrorists. ${ }^{8}$ In his article, "Want to Torture? Get a Warrant," Dershowitz asserts that torture should necessarily be used if there is an "absolute need to obtain immediate information in order to save lives, coupled with probable clause that the suspect has such information and is unwilling to reveal it."' In essence, he suggests that although the pain of torture is bad, the good produced, namely the saving of lives, makes the torture morally just. Using the specific example of the state of Israeli's legal use of torture in certain circumstances but speaking in the hypothetical, Dershowitz argues that the lives of "a thousand innocent people" should be "valued more than the bodily integrity" of one potentially guilty person. ${ }^{10}$ Within this argument, the terrorist has undergone a transformation in which he is no longer a sinful human being, but rather a stock resource of information, which can

6 Ibid.

7 Cornell University Law School: Legal Information Institute. "United States Code," accessed April 11, 2012, http://www.law.cornell.edu/uscode/text. 8 Professor Dershowitz retired in December of 2013.

9 Alan Dershowitz, "Want to Torture? Get a Warrant," San Francisco Chronicle, January 22, 2002, accessed June 2, 2012, http://www.sfgate.com/opinion/ openforum/article/Want-to-torture-Get-a-warrant-2880547.php.

10 Alan Dershowitz, Why Terrorism Works: Understanding the Threat, Responding to the Challenge, (New Haven: Yale University Press, 2002), 144. 


\section{The Notion of Subhuman Identity in the War on Terror}

and should be used to save the "innocent."11

Despite the divergent views surrounding the humanness of suspected terrorists, torture remains a standard part of procedure at the American detention facility, Guantanamo Bay. Former detainees claim that upon arrival, they were unapologetically informed of their inferior status, with statements such as: "You are now the property of the U.S. Marine Corps." 12 The detainees further allege they were frequently degraded, humiliated and tormented, all as part of the United States' plan to extract information. As Giorgio Agamben notes, these detainees were reduced to a "bare life" status, in which they were deprived of any form of agency over their own lives. ${ }^{13}$ Their lives were included in the juridical order solely in the form of exclusion; that is, they were kept alive only to be dehumanized and used as tools in the capturing of other suspected terrorists. Why were al Qaida and Taliban militants treated outside of existing boundaries concerning the ethical treatment of human beings? Further, how is it that the United States acquired the ultimate authority in determining the rights and non-rights of these militants? The question of how such widely contested forms of treatment came to be permitted in a state that powerfully advocates for the universal ethical treatment of human beings is one with an intricate answer. From here, I will use Carl Schmitt's theory on the political phenomenon of sovereignty and the "exception," in conjunction with a legal analysis to illustrate the foundations for such unprecedented state authority. ${ }^{14}$

Evidenced through the legally sanctioned, degrading treatment of suspected terrorists in Guantanamo Bay, the U.S. Government acquired the ultimate authority in determining the humanness of al Qaida and Taliban combatants. Carl Schmitt's theory on the political phenomenon of sovereignty and the "exception" explains the foundations for such state authority. ${ }^{15}$ Schmitt contends that in each community there exists a set of actors who hold enough power to

11 Ibid.

12 Michael Otterman, American Torture: From the Cold War to Abu Ghraib and Beyond, (Victoria: Melbourne University Press, 2007), 137.

13 Giorgio Agamben, State of Exception, trans. Kevin Attel, (Chicago: The University of Chicago Press, 2005), 4.

14 Carl Schmitt, Political Theology: Four Chapters on the Concept of Sovereignty, trans. George Schwab, (Chicago: University of Chicago Press, 2005), 6.

15 Ibid. 
decide if, and when, to suspend the conventional legal order. These actors are much like the gods of the political state, in that they hold a kind of metaphysical power that allows them to transcend the law when circumstances demand. A "state of exception" is thus created when these actors determine that an extraordinary emergency exists for the state, and that it is in the state's best interest to not only suspend, but to also transcend the existing law. ${ }^{16}$

The exclusive power to decide on the "exception" is the foundation for the establishment of Guantanamo Bay, as well as for President Bush's (terms of office 2001-2009) Military Order of November 13, 2001, regarding the "Detention, Treatment, and Trial of Certain NonCitizens in the War against Terrorism." ${ }^{17}$ As Giorgio Agamben asserts, the "state of exception appears as a threshold of interdeterminancy between democracy and absolutism." ${ }^{18}$ In this way, Guantanamo Bay is a constant embodiment of the "state of exception" because it exists in the realm of legal limbo. Since the facility is not on American land, it is exempt from the American Constitution. It is the only American military institution located inside the territory of a state that does not have formal diplomatic relations with the United States. It detains al Qaida and Taliban militants whose existence is considered to be so outside of the boundaries of humanity, that the facility was exclusively created for their incarceration. The treatment of these militants under American custody is unlike anything that other criminals in the United States endure. It is for this reason that the imprisoned militants themselves are constant embodiments of the "state of exception." The American Government legally recognizes them as "unlawful combatants."19 They fall outside of the normal bounds of political reality simply because they do not wear the uniform of a recognized political entity. Within Guantanamo Bay, these "unlawful combatants" are relentlessly tortured, most often for long, indefinite periods of time, and their inhumane treatment was legally sanctioned

16 Agamben, State of Exception, 2.

17 George W. Bush, "Detention, Treatment, and Trial of Certain Non-Citizens in the War Against Terrorism," Federal Register 66:222, November 13, 2001, accessed August 30, 2013, http://georgewbush-whitehouse.archives.gov/news/ releases/2001/11/20011113-27.html.

18 Agamben, State of Exception, 3.

19 Jennifer Elsea, Terrorism and the Law of War, (New York: Nova Science Publishers Inc., 2008), 26. 


\title{
The Notion of Subhuman Identity in the War on Terror
}

by Bush's strategic Military Order.

The passing of the controversial Military Order exemplified President Bush's position as the ultimate authority in deciding on the "exception." On November 13, 2001, he officially declared the United States' then existential "state of emergency" to eventually legitimize the unprecedented authority of the American Government in the detainment of al Qaida and Taliban militants:

\begin{abstract}
Having fully considered the magnitude of the potential deaths, injuries, and property destruction that would result from potential acts of terrorism in the United States, and the probability that such acts will occur, I have determined that an extraordinary emergency exists for national defense purposes, that this emergency constitutes an urgent and compelling government interest and that issuance of this Order is necessary to meet the emergency. ${ }^{20}$
\end{abstract}

The Bush Administration further used the national state of emergency to strategically include only vague and unspecific clauses within the Order. For example, the Order applies to any individual that the president has "reason to believe" is a member of al Qaida or "anyone causing or seeking to cause harm to the United States, its citizens, or its economy." ${ }^{21}$ Another example of the Order's intentional ambiguity is illustrated in the clause outlining the powers of the United States Secretary of Defence, which states that the Secretary of Defense "shall issue such orders and regulations as may be necessary, to carry out any of the provisions of [the] Order." ${ }^{22}$ The indistinct phrase, "such orders and regulations as may be necessary," delegates to the Secretary of Defense a nearly unlimited authority over suspected terrorists. Further, the Order states that "if," not when, a suspect is to be tried, he is to be tried by "military commission." ${ }^{23}$ Because of the relative newness of mass acts of terrorism against the United States, there are no precedents for judges and lawyers to rely upon; thus, the authorities involved in the military commissions work

20 Bush, "Detention, Treatment, and Trial."

21 Ibid.

22 Elsea, Terrorism, 46.

23 Bush, "Detention, Treatment, and Trial." 
within malleable circumstances in which statements made under torture are considered legitimate, and the death penalty is authorized. Further, the rules of the military commissions state that suspects can be "barred from attending their own trials and seeing the evidence against them." ${ }^{24}$ In this way, the accused are lawfully restricted from any opportunity of a fair trial. As evident through the imbalanced nature of the military commissions, the U.S. Government holds an unprecedented power; Bush's Military Order purposely isolates members of the Taliban and al Qaida from established legal traditions so that their fate is ultimately left in the hands of the

American Government.

The trend of "unprecedented power" is continued further in the Order, in the declaration that the American Government will treat the 9/11 attacks as "acts of war" rather than as criminal acts. ${ }^{25}$ Similar to the clause stating the powers of the Secretary of Defense, the "acts of war" clause is also intended to expand the United States' authority with as much legal certainty as possible. Under international law, an "act of war" is: "A use of force or other action by one state against another which the state acted against recognizes ... as an act of war, either by use of retaliatory force or a declaration of war." ${ }^{26}$ In a traditional sense, the 9/11 attacks were not "acts of war" because the perpetrators were not overtly acting on behalf of a state, and because they did not employ conventional military weapons. However, the Bush Administration chose to classify the acts as such to ensure justified autonomy for the United States in the War on Terror. Evident through the indistinct declarations of the Military Order, it was through both ambiguousness and untraditional legal classification that the U.S. Government was able to acquire supreme authority in its War on Terror.

Even after the enactment of the Military Order, the U.S. Government continued its expansion of power in the detainment of suspected terrorists. In October 2006, the Bush Administration enacted the "Military Commissions Act," which authorized the executive to conduct military tribunals of "unlawful enemy combatants," and to hold them indefinitely without judicial review

24 Otterman, American Torture, 138.

25 Elsea, Terrorism, vii.

26 Ibid, 14. 


\section{The Notion of Subhuman Identity in the War on Terror}

under the terms of habeas corpus. ${ }^{27}$ The Act codified the term "unlawful enemy combatant," and in doing so it invested the U.S. Government with extensive discretionary power in terms of determining who constituted such an entity. According to the Military Commissions Act, an "unlawful enemy combatant" is:

A person who has engaged in hostilities or who has purposefully and materially supported hostilities against the United States or its co-belligerents who is not a lawful enemy combatant (including a person who is part of the Taliban, al Qaida, or associated forces), and a person who, before, on, or after the date of the enactment of the Military Commissions Act of 2006, has been determined to be an unlawful enemy combatant by a Combatant Status Review Tribunal or another competent tribunal established under the authority of the President or the Secretary of Defense. ${ }^{28}$

The Military Commissions Act is an exemplification of the "systematic dehumanization" of al Qaida and Taliban militants. ${ }^{29}$ The U.S. Government created and codified the term "unlawful enemy combatant" to deliberately exclude al Qaida and Taliban militants from enjoying any of the rights of "lawful enemy combatants", and in essence, any of the basic rights of human beings. For example, unlike "lawful combatants," "unlawful combatants" do not qualify for Prisoner of War status under the Geneva Conventions. ${ }^{30}$ To further clarify and establish this exclusion, Bush unapologetically declared: "None of the provisions of Geneva apply to our conflict with al Qaida in Afghanistan or elsewhere throughout the world." 31 This Act was the rationale for erasing any legal status of al Qaida and Taliban militants, by holding them neither as criminal suspects nor as Prisoners of War, but as a third category of beings. Even though there are no

27 David K Linnan, Enemy Combatants, Terrorism, and Armed Conflict Law: A Guide to the Issues, (Connecticut: Greenwood Publishing Group, 2008), 110.

28 U.S. Government Printing Office. "Military Commissions Act of 2006." accessed August 20, 2013, http://www.gpo.gov/fdsys/pkg/PLAW-109publ366/ html/PLAW-109publ366.htm.

29 Dabashi, Brown Skin, 5.

30 Linnan, Enemy Combatants, 109.

31 Ibid. 
substantial differences in the ways in which "lawful combatants" and "unlawful combatants" engage in warfare, the Military Commissions Act strategically differentiates between the two. Because al Qaida and Taliban militants do not act on behalf of a state organization, and because they do not wear a "fixed distinctive sign," they are legally recognized as beings that are somehow outside of the boundaries of humanity. ${ }^{32}$

In addition to legally establishing a third category of beings, the Military Commissions Act stipulates that any testimony coerced through humiliating or degrading treatment is admissible. Although the Act does ban torture, the clause which references the use of torture is problematic because it only prohibits acts that are "specifically intended" to cause "severe mental and physical pain." 33 The Act integrates these ambiguous restrictions because under international law, it must comply with the War Crimes Act, which prohibits the "cruel or inhumane" treatment of enemy combatants. ${ }^{34}$ Despite the War Crimes Act's restrictions on torture, Central Intelligence Agency (CIA) agents have consistently used tormenting interrogation techniques in Guantanamo Bay. The techniques include water-boarding, sleep deprivation, induced hypothermia, and solitary confinement without a time restriction. ${ }^{35}$ According to the CIA, these techniques are "not intended to cause gratuitous, severe physical pain or suffering or prolonged mental harm," but are instead intended to "induce cooperation" over a period of time by weakening the detainee's mental and physical ability to resist. ${ }^{36}$ Surprisingly, the U.S. Government has not violated any international laws with its use of torture because under the War Crimes Act, an action is only considered "cruel or inhumane" if it produces "serious" physical or mental pain. ${ }^{37}$ Since water-boarding and solitary confinement only produce brief pain, and since induced hypothermia, sleep deprivation and hand slaps do not cause "serious" bodily injury, they are not considered "cruel or inhumane" and are thus all legal tools in the interrogator's toolbox.

32 U.S. Government, "Military Commissions Act."

33 Otterman, American Torture, 187.

34 Elsea, Terrorism, 63.

35 Otterman, American Torture, 188.

36 Ibid, 147.

37 Ibid, 187. 


\section{The Notion of Subhuman Identity in the War on Terror}

Despite the controversy surrounding the use of torture, Bush advocated for its use in the interrogations of suspected terrorists. He described the CIA's interrogation program as "the single, most potent tool that [the U.S. Government] has in protecting America and foiling terrorist attacks." ${ }^{38} \mathrm{He}$ further referred to the interrogation techniques as "an alternative set of procedures," and "vital tools that are needed to protect the American people and [their] allies." ${ }^{39} \mathrm{He}$ also continuously referred to al Qaida and Taliban militants as "the world's most dangerous terrorists" in an attempt to justify the cruel treatment towards them by placing them in a distinct category. ${ }^{40}$ Further, Bush's Vice President, Dick Cheney (terms of office 2001-2009) also publicly supported the inhumane treatment of the militants, stating: "I think [the Military Order and the Military Commissions Act] guarantee that [the U.S. Government] has the kind of treatment available for these individuals that they deserve." ${ }^{41}$ The militants are considered to constitute such a unique existence that the treatment they supposedly "deserve" is unlike any treatment given to other criminals of the United States. Bush insisted that this was because:

The War on Terror ushers in a new paradigm, one in which groups with broad, international reach commit horrific acts against innocent civilians, sometimes with the direct support of states. [The United States of America] recognizes that this new paradigm, ushered in not by [Americans], but by terrorists, requires new thinking in the law of war. ${ }^{42}$

The "new thinking" has thus far resulted in the dehumanization of enemy combatants and the establishment of a new category of beings. By integrating the ambiguous legal status of the militants into convincing rhetoric, the Bush Administration gained public acquiescence. They then used this acquiescence to enact controversial

\footnotetext{
38 Ibid, 186.

39 Ibid, 13.

40 Ibid, 186.

41 The White House, "Remarks by Vice President Dick Cheney to the U.S. Chamber of Commerce," November 14, 2001, accessed August 30, 2013, http:// georgewbush-whitehouse.archives.gov/vicepresident/news-speeches/speeches/ vp20011114-1.html.

42 Otterman, American Torture, 128.
} 
foreign policies and further, to justify the exclusion of al Qaida and Taliban combatants from both domestic and international law.

In the "state of exception," the decision on the humanness of the captured person is made by those with judicial power. Within this state, the captured, unclassifiable being, regardless of the accuracy of the accusations, loses the ability to use his voice. The individual has not only been deprived of his citizenship, but also of any form of agency over his own life. Following the 9/11 attacks, the "state of exception" became the rule in the United States. It was with this rule that the Bush Administration was able to override existing laws to create a torture facility and also to enact discriminatory foreign policies. Through both the Military Order and the Military Commissions Act, the U.S. Government acquired the ultimate authority in determining the rights of al Qaida and Taliban militants and further, the authority to decide on their humanness.

The U.S. Government exemplified its categorization of al Qaida and Taliban militants through its initiation of a unique, mechanized military operation beginning in 2004, bringing into existence a new kind of warfare, in which the traditional human element of offensive combat was replaced with preprogrammed machinery. ${ }^{43}$ In June of 2004, the Bush Administration launched a series of airborne attacks on suspected al Qaida and Taliban militants in the regions along the Afghanistan and Pakistan border. ${ }^{44}$ The ongoing attacks involve an armed, unmanned aircraft or "combat drone," which is controlled remotely either autonomously, by a computer, or by an agent from the CIA's Special Activities Division. ${ }^{45}$ Because combat drones do not require any personnel onboard, they provide constant, uninterrupted surveillance of proposed targets and their surroundings, so that an exceptionally precise attack can eventually take place. Further, the United States' drone operation does not constitute a traditional military battle because the targets are attacked without the ability to reciprocate strikes. In this way, the automated, procedural nature

43 The New America Foundation, “The Drone War in Pakistan: All Strikes," accessed August 20, 2013, http://natsec.newamerica.net/drones/pakistan/ analysis?page $=17$.

44 Ibid.

45 Bobby Ghosh and Mark Thompson, “The CIA's Silent War in Pakistan," TIME Magazine, June 1, 2009, accessed April 20, 2013, http://www.time.com/time/ magazine/article/0,9171,1900248,00.html. 


\section{The Notion of Subhuman Identity in the War on Terror}

of drone warfare has removed the human essence from offensive warfare, which in effect has created an asymmetrical war.

Since al Qaida and Taliban militants do not wear the uniform of any "recognized state army," there are conceptual difficulties in fitting their activities into the rigid grid of the international law of war. ${ }^{46}$ However, the U.S. Government contends that the drone operation is completely legitimate, as cited in a March 2010 statement from then U.S. Legal Advisor, Harold Koh. Koh adamantly insisted that the United States' "targeting practices, including lethal operations conducted with the use of unmanned aerial vehicles," complied with "all applicable law, including the laws of war." ${ }^{47}$

The U.S. Government has strategically interpreted the international law of war in order to legitimize and continue its drone mission. Both the Bush and Obama Administrations have contended that the drone strikes are lawful acts of war, as well as a means of "self-defense" in what they perceive to be an "armed conflict" with al Qaida and the Taliban. ${ }^{48}$ The U.S. Government has established the position that it has the right to kill in accordance with the "Authorization to Use Military Force," or as an "act of self-defense" when:

(i) It identifies an individual who is part of al Qaida, the Taliban, or associated forces;

(ii) The individual poses an imminent threat to American interests at home or abroad;

(iii) [The individual's] capture is infeasible. ${ }^{49}$

Similar to the indistinct clauses of both the Military Order and the Military Commissions Act, the U.S. Government once again intentionally included capacious definitions of when it might exercise particular powers, including lethal force. For example, they

46 Elsea, Terrorism, 13.

47 Greg Bruno, "U.S. Drone Activities in Pakistan," Council on Foreign Relations, July 19, 2010, accessed March 13, 2012, http://www.cfr.org/pakistan/us-droneactivities-pakistan/p22659.

48 Ibid.

49 David Cole, "Obama and Terror: The Hovering Questions," The New York Review of Books, July 12, 2012, accessed August 20, 2013, http://www. nybooks.com/articles/archives/2012/jul/12/obama-and-terror-hoveringquestions/?pagination=false. 
strategically included the term "imminent threat," contending that al Qaida militants want to strike the United States whenever they have a chance and therefore always pose an "imminent threat" to American safety. ${ }^{50}$

An "international armed conflict" is legally understood as a war between states, and not a war between states and "non-state actors." 1 Both al Qaida and the Taliban are considered "non-state actors" under international law, which means that the United States' "self-defense" claim in this context of conflict is invalid. ${ }^{52}$ Even though al Qaida and the Taliban have attacked the United States, the use of force by private persons has not traditionally constituted an "armed conflict." 53 Additionally, the United States' claim that

the drone strikes are legitimate "acts of war" is highly problematic, as neither Afghanistan nor Pakistan has attacked the United States. The United States' nonconformity to the law of war and the unconventional nature of its drone mission could potentially result in its violation of the law of war. As Georgetown University professor Gary Solis, suggests, the agents involved with the implementation of the drone operation may be subject to prosecution, albeit with some irony, as "unlawful combatants." 54

Despite the legal discrepancies and the asymmetrical nature of the United States' drone operation, President Obama (elected to office 2009) continues to justify and support the United States' military intervention along the border between Afghanistan and Pakistan. $\mathrm{He}$ insists that the drone strikes are needed not only because it is "necessary" to destabilize al Qaida and the Taliban, but also because the drone strikes supposedly have superior precision when compared to conventional military tactics. ${ }^{55}$ According to reports from the CIA and the United States military, the drone strikes have seldom result

50 Ibid.

51 Ibid.

52 Elsea, Terrorism, 15.

53 Ibid, 13.

54 Gary Solis, "CIA Drone Attacks Produce America's own Unlawful Combatants," The Washington Post, March 12, 2010, accessed August 20, 2013, http://www. washingtonpost.com/wp-dyn/content/article/2010/03/11/AR2010031103653. html.

55 Cole, "Obama and Terror." 


\section{The Notion of Subhuman Identity in the War on Terror}

in civilian fatalities. ${ }^{56}$ The CIA claims that only a minimal number of civilian deaths have occurred since the operation's initiation, and that since 2008, the drone strikes have primarily killed only those targeted. ${ }^{57}$ This claim is highly unlikely, as drone missiles are most often launched in areas where people fit the generic description of "hostile enemy combatants," so as to increase the probability of striking actual "unlawful enemy combatants." ${ }^{2}$ The drone operators senselessly kill anyone they identify as an enemy without any concrete evidence of their identity and behaviour. As a result, innocents who go about their daily business, as well as the friends and family members who surround them, are often the unsuspecting targets of drone strikes. In this way, the CIA's statistics are nowhere near the actual number of civilian deaths; some independent research suggests that during the Obama Administration alone, drone tactics have killed as many as five hundred civilians. ${ }^{59}$ Despite such statistics, President Obama continues to expand the drone operation in a way that supersedes the accomplishments of his predecessor; of a total of 383 CIA drone strikes launched against al Qaida and Taliban combatants between 2004 and 2014, only 51 were launched by the Bush Administration. ${ }^{60}$

Obama's campaign may protect the citizens of the United States, but it transforms the environments of the accused and innocent alike into a remote-controlled killing game. With its procedural and mechanized nature, the drone war is a high tech war that has "created the impression, albeit an erroneous one, that war itself has become bloodless." ${ }^{61}$ From the attacker's point of view, the drone war takes

56 Daniel L. Byman, "Why Drones Work: The Case for Washington's Weapon of Choice," The Brookings Institution, July 2013, accessed August 20, 2013, http:// www.brookings.edu/research/articles/2013/06/17-drones-obama-weaponchoice-us-counterterrorism-byman.

57 Mark Landler, "Civilian Deaths Due To Drones Are Not Many, Obama Says," The New York Times, January 30, 2012, accessed June 21, 2012, http://www. nytimes.com/2012/01/31/world/middleeast/civilian-deaths-due-to-drones-arefew-obama-says.html?_r=0.

58 Cole, "Obama and Terror."

59 Byman, "Why Drones Work."

60 "Covert Drone War: Casualty Estimates," The Bureau of Investigative Journalism, accessed March 28, 2014, http://www.thebureauinvestigates.com/ category/projects/drones.

61 Th.A. van Baarda and D.E.M. Verweij, eds., "Introduction," in The Moral Dimension of Asymmetrical Warfare, eds. Th.A. van Baarda and D.E.M. Verweij, 
place through an intricately constructed simulation of the battlefield, in which the enemy is illustrated as a faceless target. The dehumanized essence of drone warfare creates an eerie parallel between the United States' drone operation and a war-themed videogame. Like the agent who controls a combat drone, the player of a videogame is the controller of an operation with a clear objective. Disconnected from the reality of combat, the player sits behind a screen and pushes various buttons to attack his opponents. He has total control; he decides when to attack, which weapons to use, and ultimately, when to turn off the game. Similarly, drone operators monitor their targets intimately through lifelike simulations of the enemy combatant and his environment. They too decide when to attack and which of the drones is best suited for the attack. The ultimate player, the United States, decides when to turn off the operation. With such parallels, the operators of the United States' drone mission are quintessentially the players of a legally sanctioned videogame. ${ }^{62}$

In contrast to the systematic dehumanization of accused enemies detained as part of the War on Terror, criminally accused American citizens are given the opportunity to defend themselves by law. Once enough evidence has been gathered, a legal community determines their fate through adherence to the definite laws within the American Constitution. In the context of the United States' drone operation, however, the fate of the accused lies in the hands of the operators, who dispense of human life at their discretion. The only evidence they need is their own judgment on whether an individual appears to be a "hostile" enemy combatant. ${ }^{63}$ In this way, the drone war has evolved the United States' war against al Qaida and the Taliban into a

(Leiden: Martinus Nijhoff Publishers, 2009), 16.

62 The parallels between the United States' drone operation and modern videogames involving warfare exemplify the transformation of the enemy combatant from human being to stock object. In a videogame, the opponents have no individual identity other than that of an enemy. Similarly, within the drone operation, Taliban and al Qaida militants are identified exclusively by their existence as "unlawful enemy combatants." For this reason, many militants are often killed simultaneously with a single drone strike. Such strikes are known as "signature strikes" and they target and kill groups of men who are not personally identified but who appear to be combatants. Cole, "Obama and Terror."

63 Van Baarda and D.E.M. Verweij, eds., "Introduction,” 16. 


\section{The Notion of Subhuman Identity in the War on Terror}

dehumanized, technological spectacle in which the enemy combatant's life is not only objectified, but fundamentally reduced in value. These men are placed so far outside of the existing boundaries of humanity that they are legitimately executed without trial through the American Government's interpretation of intentionally ambiguous laws.

The amalgamation of the American Government's foreign policies in the War on Terror and its dehumanizing military operation has created a legally sanctioned norm for the subhuman treatment of accused al Qaida and Taliban militants. Schmitt's theory on sovereignty and the "exception" explains the circumstances under which the U.S. Government was able to establish itself as the legal determinant of identity. Using Bush's 2001 recognition of the United States' "state of emergency," the American Government continues to expand its authority in its war against the Taliban and al Qaida, without effective domestic or international interference. Together, the Military Order and the Military Commissions Act legally allow the U.S. Government to codify its own notion of subhuman identity. This unique identity is entrenched within American law under the term "unlawful enemy combatant," and it is presently only assigned to members of the Taliban and al Qaida. Through its several unique and often unprecedented mediums, the American Government treats "unlawful enemy combatants" as inferior beings. The detainees in Guantanamo Bay are a constant exemplification of how the U.S. Government segregates and exclusively treats those whom it determines to be outside of the existing boundaries of humanity. Within Guantanamo Bay, the interrogator's use of torture to extract information, which may or may not exist, constitutes a means to an end and the categorization of the accused as an object.

Within the CIA's drone war, the deaths of enemy combatants are regarded as mechanical and procedural necessities. Thus, these drone operations are also a constant exemplification of the American Government's notion of al Qaida and Taliban militants as beings who do not meet the requirements for human identity. As Agamben notes, through their unique treatment in Guantanamo Bay as detainees, and through their procedural deaths on their own land as "unlawful enemy combatants," al Qaida and Taliban militants have been reduced to a "bare life" status in which they have lost all forms of agency over 


\section{Jessica Singh}

their own lives. ${ }^{64}$ These militants are treated by the U.S. Government as beings that belong to the most inferior category in a hierarchical model of humanness. Despite the United States' decision to create an exclusive facility to house al Qaida and Taliban combatants, the codification and entrenchment of a preconceived notions, and the subsequent launch of an asymmetrical war, the U.S. Government is, and will continue to be the ultimate, self-appointed authority in the decision-making process regarding the humanness of the captured because of its exclusive authority to supersede all existing law within the state of exception.

\section{Bibliography}

Agamben, Giorgio. State of Exception. Translated by Kevin Attel.

Chicago: The University of Chicago Press, 2005.

http://dx.doi.org/10.7208/chicago/9780226009261.001.0001

Bruno, Greg. "U.S. Drone Activities in Pakistan." Council on Foreign Relations, July 19, 2010. Accessed March 13, 2012. http://www. cfr.org/pakistan/us-drone-activities-pakistan/p22659.

Bush, George W. "Detention, Treatment, and Trial of Certain Non-Citizens in the War Against Terrorism." Federal Register 66:222, November 13, 2001. Accessed August 30, 2013. http://georgewbush-whitehouse.archives.gov/news/ releases/2001/11/20011113-27.html.

Byman, Daniel L. “Taliban vs. Predator.” Foreign Affairs, March 18, 2009. Accessed March 14, 2012. http://www.foreignaffairs.com/ articles/64901/daniel-byman/taliban-vs-predator.

Byman, Daniel L. "Why Drones Work: The Case for Washington's Weapon of Choice." Brookings, July 2013. Accessed August 20, 2013. http://www.brookings.edu/research/articles/2013/06/17drones-obama-weapon-choice-us-counterterrorismbyman.

64 Agamben, State of Exception, 4. 


\section{The Notion of Subhuman Identity in the War on Terror}

Cole, David. "Obama and Terror: The Hovering Questions." The New York Review of Books, July 12, 2012. Accessed August 20, 2013. http://www.nybooks.com/articles/archives/2012/jul/12/obamaand-terror-hovering-questions/?pagination=false.

Cornell University Law School: Legal Information Institute. "United States Code." Accessed April 11, 2012. http://www.law.cornell. edu/uscode/text.

Dabashi, Hamid. Brown Skin, White Masks. New York: Pluto Press, 2011.

Dershowtiz, Alan. Rights from Wrongs: A Secular Theory of the Origins of Rights. New York: Basic Books, 2004.

Dershowtiz, Alan. "Want to Torture? Get a Warrant." San Francisco Chronicle, January 22, 2002. Accessed June 2, 2012. http://www. sfgate.com/opinion/openforum/article/Want-to-torture-Get-awarrant-2880547.php.

Dershowitz, Alan. Why Terrorism Works: Understanding the Threat, Responding to the Challenge. New Haven: Yale University Press, 2002.

Elsea, Jennifer. Terrorism and the Law of War. New York: Nova Science Publishers Inc., 2008.

Ghosh, Bobby and Thompson, Mark. “The CIA's Silent War in Pakistan.” TIME Magazine, June 1, 2009. Accessed April 20, 2013. http://www.time.com/time/magazine/ article/0,9171,1900248,00.html.

Landler, Mark. "Civilian Deaths Due To Drones Are Not Many, Obama Says." The New York Times, January 30, 2012. Accessed June 21, 2012. http://www.nytimes.com/2012/01/31/world/ middleeast/civilian-deaths-due-to-drones-are-few-obama-says. html?_r=0. 


\section{Jessica Singh}

Linnan, David K. Enemy Combatants, Terrorism, and Armed Conflict Law: a Guide to the Issues. Westport: Greenwood Publishing Group, 2008.

Lockman, Zachary. Contending Visions of the Middle East: The History and Politics of Orientalism, $2^{\text {nd }}$ ed. New York: Cambridge University Press, 2010. http://dx.doi.org/10.1017/cbo9780511804342

Otterman, Michael. American Torture: From the Cold War to Abu Ghraib and Beyond. Victoria: Melbourne University Press, 2007.

Schmitt, Carl. Political Theology: Four Chapters on the Concept of Sovereignty. Translated by George Schwab. Chicago: University of Chicago Press, 2005. http://dx.doi.org/10.7208/chicago/9780226738901.001.0001

Solis, Gary. "CIA Drone Attacks Produce America’s own Unlawful Combatants." The Washington Post, March 12, 2010. Accessed August 20, 2013. http://www.washingtonpost.com/wp-dyn/ content/article/2010/03/11/AR2010031103653.html.

The Bureau of Investigative Journalism. "Covert Drone War: Casualty Estimates." Accessed March 28, 2014. http://www. thebureauinvestigates.com/category/projects/drones.

The New America Foundation. "The Drone War in Pakistan: All Strikes.” Accessed August 20, 2013. http://natsec.newamerica. net/drones/pakistan/analysis?page $=17$.

The White House. "Remarks by Vice President Dick Cheney to the U.S. Chamber of Commerce.” November 14, 2001. Accessed August 30, 2013, http://georgewbush-whitehouse.archives. gov/vicepresident/news-speeches/speeches/vp20011114-1. html. 
The Notion of Subhuman Identity in the

War on Terror

United States Government Printing Office. "Military Commissions Act of 2006." Accessed August 20, 2013. http://www.gpo.

gov/fdsys/pkg/PLAW-109publ366/html/PLAW-109publ366. htm.

Van Baarda, Th.A., and Verweij, D.E.M., eds., The Moral Dimension of Asymmetrical Warfare. Leiden: Martinus Nijhoff Publishers, 2009. http://dx.doi.org/10.1163/ej.9789004171299.i-532 